Article

\title{
Chemical Composition and Antimicrobial Activity of the Essential Oils from Three Chemotypes of Origanum vulgare L. ssp. hirtum (Link) Ietswaart Growing Wild in Campania (Southern Italy)
}

\author{
Laura De Martino $^{1, *}$, Vincenzo De Feo ${ }^{1}$, Carmen Formisano ${ }^{2}$, Enrico Mignola ${ }^{2}$ and
} Felice Senatore $^{2}$

1 Dipartimento di Scienze Farmaceutiche, Università degli Studi di Salerno, via Ponte don Melillo, 84084 Fisciano (Salerno), Italia; E-mail: defeo@unisa.it (V.D.F.)

2 Dipartimento di Chimica delle Sostanze Naturali, Università degli Studi di Napoli, "Federico II”, Via D. Montesano, 49, 80131 Napoli, Italia; E-mails: caformis@unina.it (C.F.), mignolaenrico@alice.it (E.M.), fesenato@unina.it (F.S.)

* Author to whom correspondence should be addressed; E-mail: 1demartino@unisa.it; Tel.: +39089969751; Fax: +39089969602

Received: 29 June 2009; in revised form: 20 July 2009 / Accepted: 22 July 2009 /

Published: 27 July 2009

\begin{abstract}
Essential oils obtained from inflorescences of three Origanum vulgare L. ssp. hirtum (Link) Ietswaart samples, growing wild in different locations in Campania (Southern Italy), were analysed. Three chemotypes were found: the first, with a prevalence of carvacrol/thymol; the second, characterized by the prevalence of thymol/ $\alpha$-terpineol; the third, featuring a prevalence of linalyl acetate and linalool. This chemical study attempts to provide a contribution in shedding light on the relationship between chemical composition and biotypes and/or chemotypes in Origanum vulgare ssp. hirtum. The essential oils were also evaluated for their antibacterial activity against 10 selected microorganisms. The data obtained contribute to the future view to use the essential oils as natural preservatives for food products, due to their positive effect on their safety and shelf life.
\end{abstract}

Keywords: Origanum vulgare ssp. hirtum; essential oil composition; thymol; carvacrol; linalyl acetate; antibacterial activity 


\section{Introduction}

Many different species, commonly known as oregano or origanum, are of economic interest, although they belong to different botanical families and genera. Four main groups commonly used for culinary purposes can be distinguished, i.e., Greek oregano (Origanum vulgare L. ssp. hirtum (Link) Ietswaart), Spanish oregano (Coridothymus capitatus (L.) Hoffmanns \& Link), Turkish oregano (Origanum onites L.) and Mexican oregano (Lippia graveolens HBK) [1-3]. In Europe and, in general, all over the world, the most commonly found oregano species belong to the botanical genus Origanum. Within this genus, Ietswaart [4], based on morphological criteria, recognised three groups, 10 sections, 38 species, six subspecies and 17 hybrids. Before 1980, O. vulgare L. referred indifferently the subspecies that Ietswaart later identified as O. vulgare L. ssp. hirtum (Link) Ietswaart, O. vulgare L. ssp. gracile (C. Koch) Ietswaart, O. vulgare L. ssp. vulgare, and O. vulgare L. ssp. viride (Boiss.) Hayek. The $O$. vulgare subspecies are not easily distinguishable by their morphological aspects alone. It is not surprising that many analytical investigations about oregano essential oils did not discriminate between the numerous subspecies that show subtle morphological and chemical differences. The characteristics which seem to be quite constant are the yield and the composition of their essential oils, thus being these characteristics useful for subspecies identification. O. vulgare L. ssp. vulgare and $O$. vulgare ssp. hirtum (Link) Ietswaart are commercial species. A few references have reported on the first species [5-8], while more numerous works have dealt with the second [8-14], even if the reported data can vary widely probably depending on the different growing conditions and geographical areas in which the analyzed plants were collected [2]. Origanum vulgare L. ssp. hirtum (Link) Ietswaart is a typical East Mediterranean taxon. Ecologically, this species prefers warm, sunny habitats and loose, often rocky, calcareous soils, usually low in moisture content. Though very variable in morphological aspects, it can be distinguished from other $O$. vulgare subspecies by its hairy stems, compact inflorescences, leaves and calyces densely covered with glandular structures, green bracts, which are usually as long as calyces, and white flowers [15]. A number of studies have shown that $O$. vulgare ssp. hirtum is a very variable taxon both in morphological and in chemical features [16], with an essential oil whose principal components are phenols, $p$-cymene, and $\gamma$-terpinene [2]. As a continuation of our research on the oils of the Lamiaceae growing wild in Southern Italy [17-22], in this work we examined the composition of the essential oils of three O. vulgare L. ssp. hirtum populations growing wild in Campania (Southern Italy) and their antimicrobial activity on ten selected microorganism. O. vulgare ssp. hirtum is largely employed as an aromatizer in both traditional and modern foods, namely in Southern part of Italy. Its use is very old and this plant is often collected from wild populations, dried and then preserved in kitchen cupboards.

\section{Results and Discussion}

\section{Chemical composition of the essential oils}

The isolated oils were dried over anhydrous sodium sulphate and stored at $4-6{ }^{\circ} \mathrm{C}$ under $\mathrm{N}_{2}$. The dry materials gave yellow-reddish oils in a yield 2.35\% (w/w, F), 3.15\% (w/w, S), and 2.93\% (w/w, SG) of essential oil, characterized by a typical odour. 
Table 1 shows the relative percentage of the volatile components identified in the oils; compounds are listed according to their linear retention indices (LRIs) on a HP 5MS column. A total of 64 compounds have been identified in the three oils. The essential oil composition of the three populations of plants appeared quite different and allows us to identify three different chemotypes. In fact, the first and second oil were characterized by high percentages of phenols, but while the Furore oil (F) can be classified as a carvacrol/thymol chemotype, the Sanza sample (S) can be classified as a thymol/a-terpineol chemotype. The oil from San Giovanni a Piro (SG) could be classified as a linalyl acetate/linalool chemotype, with these compounds accounting for $15.90 \%$ and $12.50 \%$, respectively. In $\mathrm{F}$, the total phenol content represents $45.70 \%$ of the oil with comparable percentages of carvacrol, thymol and their derivatives (23.34\% and $22.16 \%$, respectively). In S, total phenols represent $40.50 \%$ of the oil with a prevalence of thymol and its derivatives $(29.33 \%)$ while in SG the phenolic fraction accounted to $6.30 \%$ of the oil, the half of which is represented by thymol $(3.24 \%)$. Monoterpene hydrocarbons were present in different amounts: $11.60 \%, 15.60 \%$ and $26.30 \%$, respectively for the F, $\mathrm{S}$ and SG oil, but in all cases $\gamma$-terpinene and $p$-cymene were the most abundant. $\gamma$-Terpinene and $p$ cymene, the biosynthetic precursors of monoterpenoid phenols, were present in the same amount in the oil F (2.38\% and $2.81 \%$, respectively), while in the oil S $\gamma$-terpinene $(4.59 \%)$ was detected in a higher percentage than in the oil $\mathrm{F}$, but it wasn't the same for $p$-cymene $(1.25 \%)$. However, in both cases, the two monoterpene hydrocarbons, $\gamma$-terpinene and $p$-cymene, were constantly present in the essential oils analysed, but always in lower amounts than those of the phenols, according to the results described by a previous paper [17]. The oxygenated monoterpenes represent $5.60 \%$ (F), $21.60 \%$ (S) and $33.70 \%$ (SG) of the oils. In the oils were totally detected 22 sesquiterpene hydrocarbons that ranged between $21.60 \%(\mathrm{~F})$ and $12.70 \%(\mathrm{~S})$. In all oils, $\gamma$-muurolene $(4.48 \%-2.59 \%)$, (E)- $\beta$ caryophyllene (4.29\%-2.11\%), $\beta$-bisabolene $(4.13 \%-2.51 \%)$ and $\delta$-cadinene $(3.17 \%-0.09 \%)$ were the most abundant sesquiterpenes of this fraction being the other components present in lower amounts, traces or absent. Oxigenated sesquiterpenes the most abundant were $\alpha$-cadinol $(4.02 \%-1.06 \%)$ and spathulenol (3.90\%-1.20\%).

Table 1. Essential oil composition (\% of total) of aerial parts of $O$. vulgare ssp. hirtum (Lamiaceae) growing wild in Southern Italy.

\begin{tabular}{|c|c|c|c|c|c|c|}
\hline $\mathbf{K}_{\mathbf{i}}^{\mathbf{a}}$ & $\mathbf{K}_{\mathbf{i}}^{\mathbf{b}}$ & Compound & Identification $^{\mathbf{c}}$ & $\mathbf{F}^{\mathbf{d}}$ & $\mathbf{S}^{\mathbf{d}}$ & $\mathbf{S G}^{\mathbf{d}}$ \\
\hline 925 & 1013 & Tricyclene & LRI, MS & $0.29 \pm 0.02$ & $0.20 \pm 0.01$ & $0.10 \pm 0.01$ \\
928 & 1035 & $\alpha$-Thujene & LRI, MS & $0.11 \pm 0.01$ & $0.28 \pm 0.01$ & $0.21 \pm 0.01$ \\
938 & 1075 & $\alpha$-Pinene & LRI, MS, Co-GC & $0.19 \pm 0.03$ & $0.42 \pm 0.01$ & $0.19 \pm 0.02$ \\
945 & 1056 & Camphene & LRI, MS, Co-GC & $0.50 \pm 0.02$ & $\mathrm{t}$ & $0.22 \pm 0.01$ \\
973 & 1132 & Sabinene & LRI, MS, Co-GC & $0.20 \pm 0.01$ & $0.28 \pm 0.04$ & $0.88 \pm 0.03$ \\
978 & 1118 & $\beta$-Pinene & LRI, MS, Co-GC & $0.11 \pm 0.01$ & $0.32 \pm 0.03$ & $0.40 \pm 0.01$ \\
980 & 1154 & 1 -Octen-3-ol & LRI, MS & $0.30 \pm 0.04$ & $0.30 \pm 0.01$ & \\
983 & 1253 & Octan-3-one & LRI, MS & $\mathrm{t}$ & $0.10 \pm 0.01$ & \\
993 & 1173 & Myrcene & LRI, MS, Co-GC & $0.70 \pm 0.09$ & $0.90 \pm 0.06$ & $2.80 \pm 0.20$ \\
1001 & 1146 & $\delta^{2}$-Carene & LRI, MS & $0.11 \pm 0.01$ & $0.30 \pm 0.02$ & $0.22 \pm 0.01$ \\
1005 & 1150 & $\alpha$-Phellandrene & LRI, MS, Co-GC & $0.29 \pm 0.02$ & $0.50 \pm 0.03$ & $0.08 \pm 0.00$ \\
1008 & 1160 & $\delta^{3}$-Carene & LRI, MS & $0.27 \pm 0.02$ & $1.10 \pm 0.10$ & $0.19 \pm 0.02$ \\
\hline
\end{tabular}


Table 1. Cont.

\begin{tabular}{|c|c|c|c|c|c|c|}
\hline $\mathbf{K}_{\mathbf{i}}^{\mathbf{a}}$ & $\mathbf{K}_{\mathbf{i}}^{\mathbf{b}}$ & Compound & Identification $^{\mathrm{c}}$ & $F^{d}$ & $S^{d}$ & $S_{G^{d}}$ \\
\hline 1013 & 1189 & $\alpha$-Terpinene & LRI, MS, Co-GC & $0.33 \pm 0.03$ & $0.50 \pm 0.03$ & $0.41 \pm 0.03$ \\
\hline 1025 & 1278 & $p$-Cymene & LRI, MS, Co-GC & $2.81 \pm 0.20$ & $1.25 \pm 0.3$ & $2.01 \pm 0.10$ \\
\hline 1029 & 1218 & $\beta$-Phellandrene & LRI, MS, Co-GC & $0.19 \pm 0.02$ & $0.15 \pm 0.00$ & $0.09 \pm 0.01$ \\
\hline 1030 & 1205 & Limonene & LRI, MS, Co-GC & $0.27 \pm 0.01$ & $1.21 \pm 0.3$ & $2.36 \pm 0.20$ \\
\hline 1034 & 1213 & $1,8-\mathrm{C}$ & LRI, MS, Co-GC & $0.50 \pm 0.03$ & $0.50 \pm 0.04$ & $0.60 \pm 0.03$ \\
\hline 1038 & 1243 & $(Z)-\beta-O c i m$ & LRI, MS & $0.83 \pm 0.04$ & $0.69 \pm 0.01$ & $4.64 \pm 0.40$ \\
\hline 1049 & 1262 & $(E)$ - $\beta$-Ocimene & LRI, MS & $0.22 \pm 0.01$ & $1.71 \pm 0.30$ & $4.10 \pm 0.20$ \\
\hline 1057 & 1256 & $\gamma$-Terpinene & LRI, MS, Co-GC & $2.38 \pm 0.40$ & $4.59 \pm 0.80$ & $4.90 \pm 0.10$ \\
\hline 1086 & 1265 & Terpinolene & LRI, MS & $1.80 \pm 0.5$ & $1.20 \pm 0.1$ & $0.50 \pm 0.03$ \\
\hline 1097 & 1553 & Linalool & LRI, MS, Co-GC & $2.87 \pm 0.30$ & $4.10 \pm 0.2$ & $12.50 \pm 0.7$ \\
\hline 1128 & 1638 & cis-p-Menth-2-en-1-ol & LRI, MS & $0.13 \pm 0.01$ & $\mathrm{t}$ & \\
\hline 1167 & 1718 & & LRI, MS, Co-GC & $0.33 \pm 0.01$ & $0.29 \pm 0.02$ & $\mathrm{t}$ \\
\hline 1176 & 1611 & Terpine & LRI, MS & $1.07 \pm 0.20$ & $0.41 \pm 0.01$ & $0.80 \pm 0.01$ \\
\hline 1189 & 1706 & $\alpha-\mathrm{Te}$ & LRI, MS & $0.22 \pm 0.03$ & $15.10 \pm 0.6$ & $3.90 \pm 0.10$ \\
\hline 1239 & 1607 & Thymol methyl ether & RI, MS, Co-GC & $3.81 \pm 0.60$ & $2.27 \pm 0.20$ & $1.11 \pm 0.10$ \\
\hline 1245 & 1975 & Carvacrol methyl ether & LRI, MS & $1.19 \pm 0.40$ & $4.63 \pm 0.10$ & $0.79 \pm 0.03$ \\
\hline 1259 & 1665 & Linalyl acetate & LRI, MS, Co-GC & $0.48 \pm 0.04$ & $1.20 \pm 0.1$ & $15.90 \pm 0.5$ \\
\hline 1293 & 2198 & Thymol & LRI, MS, Co-GC & $18.21 \pm 0.80$ & $26.75 \pm 0.70$ & $3.24 \pm 0.30$ \\
\hline 1299 & 2239 & Carva & LRI, MS, Co-GC & $21.89 \pm 0.70$ & $6.45 \pm 0.65$ & $0.46 \pm 0.02$ \\
\hline 1348 & 1466 & $\alpha$-Cubebene & RI, MS & $0.20 \pm 0.01$ & $0.10 \pm 0.01$ & $0.10 \pm 0.00$ \\
\hline 1353 & 2186 & Eugenol & RI, MS, Co-GC & $0.20 \pm 0.02$ & & \\
\hline 1356 & 1868 & Thymy & LRI, & $0.14 \pm 0.01$ & $0.31 \pm 0.00$ & $0.49 \pm 0.01$ \\
\hline 1367 & 1890 & Carvacryl acetate & LRI, MS & $0.26 \pm 0.02$ & $0.09 \pm 0.02$ & $0.21 \pm 0.02$ \\
\hline 1372 & 1493 & $\alpha$-Ylangene & & $0.27 \pm 0.01$ & $\mathrm{t}$ & \\
\hline 1377 & 1497 & $\alpha$-Copaene & LRI, MS & $0.29 \pm 0.03$ & $0.15 \pm 0.01$ & \\
\hline 1382 & 1549 & $\beta$-Cubebene & LRI, MS & $0.21 \pm 0.04$ & $0.25 \pm 0.02$ & $0.10 \pm 0.02$ \\
\hline 1385 & 1535 & $\beta$-Bourbonene & LRI, MS & $0.33 \pm 0.05$ & $0.20 \pm 0.01$ & $0.60 \pm 0.01$ \\
\hline 1387 & 1600 & $\beta$-Elemene & LRI, MS & $0.10 \pm 0.01$ & $0.10 \pm 0.00$ & $0.20 \pm 0.00$ \\
\hline 1415 & 1612 & (E)- $\beta$-Caryophyllene & & $3.72 \pm 0.51$ & $2.11 \pm 0.10$ & $4.29 \pm 0.3$ \\
\hline 1432 & 1612 & $\beta$-Gurjunene & LRI, MS & $0.27 \pm 0.02$ & $0.09 \pm 0.01$ & $0.19 \pm 0.01$ \\
\hline 1432 & 1650 & $\gamma$-Elemene & LRI, MS & $0.29 \pm 0.03$ & $0.22 \pm 0.02$ & $0.15 \pm 0.01$ \\
\hline 1437 & 1628 & Aromadendrene & LRI, MS & $0.21 \pm 0.00$ & $0.19 \pm 0.02$ & \\
\hline 1455 & 1689 & $\alpha$-Humulene & LRI, MS & $1.71 \pm 0.20$ & $1.48 \pm 0.20$ & $1.35 \pm 0.20$ \\
\hline 1463 & 1662 & allo-Aromadendrene & LRI, MS & $0.19 \pm 0.03$ & $0.11 \pm 0.00$ & $0.50 \pm 0.04$ \\
\hline 1477 & 1726 & Germacrene D & LRI, MS & $0.13 \pm 0.00$ & $0.41 \pm 0.02$ & $2.11 \pm 0.30$ \\
\hline 1478 & 1704 & $\gamma$-Muurolene & LRI, MS & $4.48 \pm 0.58$ & $2.59 \pm 0.20$ & $3.61 \pm 0.20$ \\
\hline 1492 & 1756 & Bicyclogermacrene & LRI, MS & $0.35 \pm 0.06$ & $0.13 \pm 0.03$ & \\
\hline 1494 & 1740 & Valencene & LRI, MS & $0.25 \pm 0.05$ & $0.17 \pm 0.02$ & $\mathrm{t}$ \\
\hline 1503 & 1740 & $\alpha$-Muurolene & LRI, MS & $0.22 \pm 0.01$ & $0.20 \pm 0.01$ & $0.39 \pm 0.01$ \\
\hline
\end{tabular}


Table 1. Cont.

\begin{tabular}{|c|c|c|c|c|c|c|}
\hline $\mathbf{K}_{\mathrm{i}}^{\mathrm{a}}$ & $\mathbf{K}_{\mathbf{i}}^{\mathbf{b}}$ & Compound & Identification $^{\mathrm{c}}$ & $F^{\mathbf{d}}$ & $S^{d}$ & $\mathrm{SG}^{\mathrm{d}}$ \\
\hline 1510 & 1743 & $\beta$-Bisabolene & LRI, MS & $4.13 \pm 0.42$ & $2.81 \pm 0.20$ & $2.51 \pm 0.20$ \\
\hline 1515 & 1776 & $\gamma$-Cadinene & LRI, MS & $0.81 \pm 0.06$ & $0.29 \pm 0.01$ & $0.35 \pm 0.01$ \\
\hline 1526 & 1773 & $\delta$-Cadinene & LRI, MS & $3.17 \pm 0.51$ & $0.99 \pm 0.1$ & $2.09 \pm 0.30$ \\
\hline 1532 & 1745 & $\alpha$-Cadinene & LRI, MS & $0.18 \pm 0.01$ & $\mathrm{t}$ & $0.21 \pm 0.00$ \\
\hline 1544 & 1854 & Germacrene B & LRI, MS & $0.09 \pm 0.01$ & $0.11 \pm 0.01$ & $0.15 \pm 0.01$ \\
\hline 1565 & 2057 & Ledol & LRI, MS & $\mathrm{t}$ & $\mathrm{t}$ & $0.10 \pm 0.00$ \\
\hline 1577 & 1250 & Spathulenol & LRI, MS & $3.90 \pm 0.40$ & $1.20 \pm 0.20$ & $1.20 \pm 0.01$ \\
\hline 1579 & 2008 & Caryophyllene oxide & LRI, MS & $1.01 \pm 0.09$ & $0.60 \pm 0.04$ & $1.20 \pm 0.1$ \\
\hline 1636 & 2183 & $\gamma$-Eudesmol & LRI, MS & $0.21 \pm 0.03$ & $0.14 \pm 0.00$ & $0.38 \pm 0.03$ \\
\hline 1640 & 2158 & t-Cadinol & LRI, MS & $2.10 \pm 0.50$ & $0.15 \pm 0.00$ & $0.19 \pm 0.02$ \\
\hline 1642 & 2209 & t-Muurolol & LRI, MS & $\mathrm{t}$ & $0.05 \pm 0.01$ & $1.51 \pm 0.20$ \\
\hline 1652 & 2235 & $\alpha$-Cadinol & LRI, MS & $1.69 \pm 0.09$ & $1.06 \pm 0.2$ & $4.02 \pm 0.3$ \\
\hline 1668 & 2219 & $\alpha$-Bisabolol & LRI, MS & $0.19 \pm 0.01$ & $\mathrm{t}$ & \\
\hline & & TOTAL & & 93.90 & 94.00 & 91.80 \\
\hline
\end{tabular}

F: Furore sample; S: Sanza sample; SG: San Giovanni a Piro sample. The values are the mean of

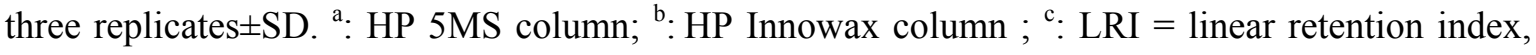
MS = mass spectrum, Co-GC $=$ co-injection with authentic compound; ${ }^{\mathrm{d}}$ : Mass of compounds in $\mathrm{mg} / 100 \mathrm{mg}$ oil; $\mathrm{t}$, trace $(<0.05 \%)$; mean value \pm standard error, $n$, three independent determinations.

The available literature [2] reports the presence of a carvacrol/thymol chemotype of O. vulgare ssp. hirtum; the others two chemotypes were described for the first time. Some papers describe the essential oil composition of $O$. vulgare ssp. hirtum from different geographic areas. Russo et al. [2] reported four chemotypes for this species, growing in Calabria (Southern Italy), on the basis of their phenolic content: thymol, carvacrol, thymol/carvacrol and carvacrol/thymol chemotypes, with the majority of samples belonging to a thymol chemotype. Kokkini et al. [16] studied the essential oils from $O$. vulgare ssp. hirtum plants collected in late autumn from six localities of three distinct geographic areas of Greece. They reported that oils of plants from the Northern part of Greece were rich in thymol, whereas those from the Southern part of the country were rich in carvacrol. Several samples rich in carvacrol were found also in Bulgaria [22].

Generally, chemotypes form "biochemical varieties" or "physiological forms" in botanical species, each of which with a specific enzymatic equipment. These species are genetically codified and direct their biosynthesis to the preferential formation of a definite compound. In the case of phenolic compounds, the metabolic pathway is through the autooxidative conversion of $\gamma$-terpinene to $p$-cymene followed by hydroxylation of $p$-cymene to thymol or carvacrol [23]. The phenols content, generally, is high during flowering stage in phenol-type origanum plant, as reported [24,25].

The characterization of habitat is of fundamental importance to understand species distribution. In a definite geographical area, the factors that weight heavily on chemotypes differentiation are mainly related to intrinsic factors such as sexual polymorphism or genetic mechanism, but for the phenolic essences, environmental conditions are able to influence biosynthetic pathway. At this regard, it is interesting note that the samples studied were collected in areas with different sun exposure. In fact, Furore is located in a sunny position, front the sea, Sanza is located in an internal zone, far from the 
sea, with temperatures lower than the other two places of sample collection, and San Giovanni a Piro is located quite near the sea. Also the season and the characteristic of plant (fresh or dried) can determinate noticeable differences in the total oil content and the concentration of the main oil components: in particular, the proportion of carvacrol has been shown to be much higher in the summer; in the autumn, $p$-cymene predominates [16,17,26].

Very few papers have reported an oregano chemotype characterized by the presence of linalyl acetate/linalool but never in O. vulgare ssp. hirtum. In fact, Perez et al. [27] reported linalool as the main volatile component of Origanum vulgare ssp. virens, characterized by a high quantity of linalool and a low quantity of thymol. D'Antuono et al. [28] reported a Northern Italian population of $O$. vulgare L. rich in linalool. On the other hand, Mockute et al. [29] showed that the main constituents of the essential oil of $O$. vulgare ssp. viride, wild in Iran, were linalyl acetate, $\beta$-caryophyllene and sabinene. Data reported in this work should help to throw light in the apparent complex chemotaxonomy of the genus Origanum.

\section{Antimicrobial activity}

The Minimum Inhibitory Concentration (MIC) and the Minimum Bacterial Concentration MBC values of the essential oils against 10 selected microorganisms are reported in Table 2. The essential oils showed action mainly against the Gram-positive pathogens, among which $S$. epidermidis was the most affected. Among Gram-negative bacteria, only E. coli was affected by the oil F. The oil F and S resulted more active than oil SG and presumably this activity is related to phenolic components, such as thymol, carvacrol, carvacrol methyl ether, though part of the activity could result from the synergistic presence of minor active constituents, such as $\gamma$-terpinene and $p$-cymene.

Table 2. MIC and MBC values ( $\mu \mathrm{g} / \mathrm{mL})$ of essential oils from Origanum vulgare L. ssp. hirtum (Link) Ietswaart growing wild in Campania and MIC of reference antibiotic. Results are the mean of three experiments.

\begin{tabular}{|c|cc|cc|cc|c|}
\hline Bacterial strain & \multicolumn{2}{|c|}{ F } & \multicolumn{2}{c|}{ S } & \multicolumn{2}{c|}{ SG } & \multirow{2}{*}{ G } \\
\hline $\begin{array}{c}\text { BIC } \\
\text { Bacillus cereus }\end{array}$ & 50 & 50 & 50 & 50 & 50 & 100 & 1.56 \\
$\quad$ ATCC 11778 & & & & & & & \\
$\begin{array}{c}\text { Bacillus subtilis } \\
\text { ATCC 6633 }\end{array}$ & 50 & 50 & 50 & 100 & 50 & 100 & 1.56 \\
$\begin{array}{c}\text { Staphylococcus aureus } \\
\text { ATCC 2592 }\end{array}$ & 50 & 50 & 50 & 50 & & 100 & 3.12 \\
$\begin{array}{c}\text { Staphylococcus epidermidis } \\
\text { ATCC 12228 }\end{array}$ & 25 & 25 & 25 & 50 & 50 & 100 & 6.25 \\
$\begin{array}{c}\text { Streptococcus faecalis } \\
\text { ATTC 29212 }\end{array}$ & 50 & 100 & 50 & 100 & 100 & 100 & $>100$ \\
$\begin{array}{c}\text { Escherichia coli } \\
\text { ATCC 25922 }\end{array}$ & 50 & 100 & 100 & 100 & 100 & 100 & 3.12 \\
\hline
\end{tabular}


Table 2. Cont.

\begin{tabular}{|c|c|c|c|c|c|c|c|}
\hline \multirow{2}{*}{ Bacterial strain } & \multicolumn{2}{|c|}{$\mathbf{F}$} & \multicolumn{2}{|c|}{$S$} & \multicolumn{2}{|c|}{ SG } & \multirow{2}{*}{ G } \\
\hline & MIC & MBC & MIC & MBC & MIC & MBC & \\
\hline $\begin{array}{l}\text { Proteus mirabilis } \\
\text { ATCC } 25933\end{array}$ & 100 & 100 & 100 & 100 & $>1$ & & 100 \\
\hline $\begin{array}{c}\text { Proteus vulgaris } \\
\text { ATCC } 13315\end{array}$ & 100 & $>100$ & 100 & 100 & $>1$ & & 100 \\
\hline $\begin{array}{c}\text { Pseudomonas aeruginosa } \\
\text { ATCC } 27853\end{array}$ & & & & & $>1$ & & 12.5 \\
\hline $\begin{array}{c}\text { Salmonella typhi Ty2 } \\
\text { ATCC } 19430\end{array}$ & 100 & 100 & 100 & 100 & $>1$ & & $>100$ \\
\hline
\end{tabular}

F: Furore sample; S: Sanza sample; SG: San Giovanni a Piro sample; G = gentamycine.

The antibacterial activity results seem to be in accordance with previous reports indicating that the essential oils, rich in phenolic compounds, possess high levels of antimicrobial activity [30-33]. Loźienè et al., [34] have reported the antimicrobial activity of phenolic compounds, such as carvacrol and thymol. It is noteworthy that has been suggested that phenolic derivatives can cause membranedisrupting activities [35]. Linalol proved to be a very active compound: in fact, Mazzanti et al., [36] reported that such component inhibited the growth of different microorganism; linalyl acetate showed bacteriostatic activity [37]. The lower antimicrobial activity of the oil SG should also be due to a synergistic presence of minor active constituents, such as $\alpha$-terpineol, thymol, $\gamma$-terpinene and p-cymene [38-43].

\section{Experimental}

\section{Plant material}

Samples of Origanum vulgare L. ssp. hirtum (Link) Ietswaart were collected from populations growing wild in different areas of Salerno province (Campania, Southern Italy) in June 2008: Furore, $600 \mathrm{~m}$ s. 1. (F), Sanza, $500 \mathrm{~m}$ s. 1. (S) and San Giovanni a Piro, $450 \mathrm{~m}$ s. 1. (SG). Voucher of each sample were stored in the Herbarium of the Salerno University: Sa 05/08, Sa 06/08 and Sa 07/08, respectively for $\mathrm{F}, \mathrm{S}$ and $\mathrm{SG}$. The representative homogeneous sample of each population was collected during "balsamic time" corresponding to the flowering stage. The plant material used for the isolation of the essential oil was air-dried at room temperature.

\section{Oil extraction}

Lots of twenty grams of dried inflorescences were hydrodistilled for three hours in a Clevenger type apparatus, as previously described [44].

\section{Gas Chromatography}

Gas Chromatography (GC) analyses were carried out using a Perkin-Elmer Sigma-115 gas chromatograph equipped with a data handling system and a flame ionization detector (FID). Separation 
was achieved by a fused-silica capillary column HP 5MS, $30 \mathrm{~m}$ length, $0.25 \mathrm{~mm}$ internal diameter, $0.25 \mu \mathrm{m}$ film thickness. The operating conditions were as follows: injector and detector temperatures, $250{ }^{\circ} \mathrm{C}$ and $280{ }^{\circ} \mathrm{C}$, respectively; oven temperature programme: $5 \mathrm{~min}$ isothermal at $40{ }^{\circ} \mathrm{C}$, subsequently at $2{ }^{\circ} \mathrm{C} / \mathrm{min}$ up to $250{ }^{\circ} \mathrm{C}$ and finally raised to $270{ }^{\circ} \mathrm{C}$ at $10{ }^{\circ} \mathrm{C} / \mathrm{min}$. Helium was used as the carrier gas $(1 \mathrm{~mL} / \mathrm{min})$. Diluted samples $(1 / 100 \mathrm{v} / \mathrm{v}$, in $n$-pentane $)$ of $1 \mu \mathrm{L}$ were manually injected at $250{ }^{\circ} \mathrm{C}$, and in the splitless mode. Analysis was also made by using a fused silica HP Innowax polyethylenglycol capillary column (50 m x $0.20 \mathrm{~mm}$ i.d.; $0.20 \mu \mathrm{m}$ film thickness). The percentage composition of the oils was computed by the normalization method from the GC peak areas. The analysis have been carried out in triplicate and the results are expressed as mean $\pm \mathrm{SD}$.

\section{Gas Chromatography - Mass Spectrometry}

Gas Chromatography-Mass Spectrometry (GC-MS) analysis was performed using an Agilent 6850 Ser. A apparatus, equipped with a fused silica HP-5 capillary column $(30 \mathrm{~m}$ x $0.25 \mathrm{~mm}$ i.d.; film thickness $0.33 \mu \mathrm{m}$ ), linked on line with an Agilent MSD 5973 Mass Selective Detector; ionization energy $70 \mathrm{eV}$, multiplier voltage $2000 \mathrm{~V}$. Mass spectra were scanned in the range 35-450 amu, scan time $5 \mathrm{scans} / \mathrm{s}$. Gas chromatographic conditions were as given above, transfer line was kept at $295{ }^{\circ} \mathrm{C}$. The oil components were identified from their GC retention indices, with either those of the literature [45-46] or with those of authentic compounds available in our laboratories. The identity of the components was assigned by comparing their linear retention indices, relative to $C_{8}-C_{28} n$-alkanes, under the same operating conditions. Further identification was made by comparison of their MS spectra on both columns, with either stored in NIST 02 and Wiley 275 libraries or with mass spectra from the literature [45-47] and our homemade library. The analyses were carried out in triplicate and the results are expressed as mean $\pm \mathrm{SD}$.

\section{Antibacterial activity}

The antibacterial activity was evaluated by determining the minimum inhibitory concentration (MIC) and the minimum bactericidal concentration (MBC), using the broth dilution method [48-50]. Ten bacterial species, selected as representative of the Gram+ and Gram- classes, were tested: Bacillus cereus (ATCC 11778), Bacillus subtilis (ATCC 6633), Staphylococcus aureus (ATCC 25923), Staphylococcus epidermidis (ATCC 12228), Streptococcus faecalis (ATTC 29212), Escherichia coli (ATCC 25922), Proteus mirabilis (ATCC 25933), Proteus vulgaris (ATCC 13315), Pseudomonas aeruginosa (ATCC 27853), Salmonella typhi Ty2 (ATCC 19430). The strains were maintained on Tryptone Soya agar (Oxoid, Milan, Italy); for the antimicrobial tests, Tryptone Soya broth (Oxoid, Milan, Italy) was used. In order to facilitate the dispersion of the oil in the aqueous nutrient medium, it was diluted with Tween 20 at a concentration of $10 \%$. Each strain was tested with sample that was serially diluted in broth to obtain concentrations ranging from $100 \mu \mathrm{g} / \mathrm{mL}$ to $0.8 \mu \mathrm{g} / \mathrm{mL}$. The sample was previously sterilized with a $0.20 \mu \mathrm{m}$ Millipore filter. The sample was stirred, inoculated with $50 \mu \mathrm{L}$ of physiological solution containing $5 \times 10^{6}$ microbial cells, and incubated for $24 \mathrm{~h}$ at $37{ }^{\circ} \mathrm{C}$. The MIC value was determined as the lowest concentration of the sample that not permit any visible growth of the tested microorganism after incubation. Control, containing only Tween 20 instead of the essential oil, was not toxic to the microorganisms. Cultures, containing only sterile physiologic 
solution Tris buffer, were used as positive control. $\mathrm{MBC}$ was determined by subculture of the tubes with inhibition in $5 \mathrm{~mL}$ of sterile nutrient broth. After incubation at $37{ }^{\circ} \mathrm{C}$ the tubes were observed. When the germs don't grow, the sample denoted a bactericidal action. Oil samples were tested in triplicate and the experiment was performed three times. The results are expressed as mean $\pm \mathrm{SD}$. Gentamycine was used as reference agent.

\section{Conclusions}

Essential oils are presently regarded as useful in food technology [51], in fact, their use in food preparation accomplishes both food flavouring and food preservation. Data obtained clearly showed the inhibitory activity of the essential oils tested against pathogenic bacteria. The available literature [52-53] shows that essential oils are natural preservatives in food and/or pharmaceutical industry: this use represents a viable and safe way to decrease the utilisation of synthetic food preservatives, due to their positive effects both on safety and shelf life.

\section{Acknowledgements}

Acknowledgments - The GC-MS spectra were performed at the "C.S.I.A.S." of the University of Naples "Federico II". The assistance of the staff is gratefully appreciated. The work was supported by a grant of the Regione Campania (Legge 5/2002).

\section{References}

1. Lawrence, B.M. The botanical and chemical aspects of Oregano. Perfum. Flavor. 1984, 9, 41-51.

2. Russo, M.; Galletti, G.C.; Bocchini, P.; Carnacini, A. Essential oil chemical composition of wild populations of Italian oregano spice (Origanum vulgare ssp. hirtum (Link) Ietswaart): A preliminary evaluation of their use in chemotaxonomy by cluster analysis. 1 . Inflorescences. $J$ Agric. Food Chem. 1998, 46, 3741-3746.

3. Bocchini, P.; Russo, M.; Galletti, G.C. Pyrolysis-Gas Chromatography/MassSpectrometry used as a microanalytical technique for the characterization of Origanum heracleoticum from Calabria, Southern Italy. Rapid Commun. Mass Spectrom. 1998, 12, 1555-1563.

4. Skoula, M.; Gotsiou, P.; Naxakis, G.; Johnson, C.B. A chemosystematic investigation on the mono- and sesquiterpenoids in the genus Origanum (Labiatae). Phytochemistry 1999, 52, 649-657.

5. Maarse, H.; Van Os, F.H.L. Volatile oil of Origanum vulgare L. ssp. vulgare. I. Qualitative composition of the oil. Flavour Ind. 1973, 4, 477-481.

6. Maarse, H.; Van Os, F.H.L. Volatile oil of Origanum vulgare L. ssp. vulgare. II. Quantitative composition of the oil. Flavour Ind. 1973, 4, 481-484.

7. Maarse, H. Volatile oil of Origanum vulgare L. ssp. vulgare. III. Changes in composition during maturation. Flavour Ind. 1974, 4, 278-281.

8. Başer, K.H.C.; Özek, T.; Tümen, G.; Sezik, E. Composition essential oil of Turkish Origanum species with commercial importance. J. Essent. Oil Res. 1993, 5, 619-623. 
9. Fleisher, A.; Sneer, N. Oregano species and Origanum chemotypes. J. Sci. Food Agric. 1982, 33, 441-446.

10. Lawrence, B.M. Origanum oil (Greek type). Perfum. Flavor. 1989, 14, 38-40.

11. Sezik, E.; Tümen, G.; Kirimer, N.; Özek, T.; Başer, K.H.C. Essential oil composition of four Origanum vulgare subspecies of Anatolian origin. J. Essent. Oil Res. 1993, 5, 425- 431.

12. Başer, K.H.C; Özek, T.; Kürkcüoglu, M.; Tümen, G. The essential oil of Origanum vulgare subsp. hirtum of Turkish origin. J. Essent. Oil Res. 1994, 6, 31-36.

13. Tucker, A.O.; Maciarello, M.J. Oregano: botany and chemistry. In Spices, Herbs and Edible Fungi; Charalambous, G., Ed.; Elsevier Science B.V: Amsterdam, The Netherlands, 1994; pp. 439- 456.

14. Melegari, M.; Severi, F.; Bertoldi, M.; Benvenuti, S.; Circetta, G.; Morone Fortunato, I.; Bianchi, A.; Leto, C.; Carubba, A. Chemical characterization of essential oils of some Origanum vulgare L. sub-species of various origin. Riv. Ital. EPPOS 1995, 16, 21-28.

15. Vokou, D.; Kokkini, S.; Bessière, J.M. Geographic variation of Greek oregano (Origanum vulgare ssp. hirtum) essential oils. Biochem. Syst. Ecol. 1993, 21, 287-295.

16. Kokkini, S.; Karousou, R.; Dardioti, A.; Krigas, N.; Lanaras, T. Autumn essential oils of greek oregano. Phytochemistry 1997, 44, 883-886.

17. Senatore, F. Influence of harvesting time on yield and composition of the essential oil of a Thyme (Thymus pulegioides L.) Growing Wild in Campania (Southern Italy). J. Agric. Food Chem. 1996, 44, 1327-1332.

18. De Feo, V.; Bruno, M.; Tahiri, B.; Napolitano, F.; Senatore, F. Chemical composition and antibacterial activity of essential oils from Thymus spinulosus Ten. (Lamiaceae). J. Agric. Food Chem. 2003, 51, 3849-3853.

19. Formisano, C.; Senatore, F.; Bruno, M.; Bellone, G. Chemical composition and antimicrobial activity of the essential oil of Phlomis ferruginea Ten. (Lamiaceae) growing wild in Southern Italy. Flavour Frag. J. 2006, 21, 848-851.

20. Basile, A.; Senatore, F.; Gargano, R.; Sorbo, S.; Del Pezzo, M.; Lavitola, A.; Ritieni, A.; Bruno, M.; Spatuzzi, D.; Rigano, D.; Vuotto, M.L. Antibacterial and antioxidant activities in Sideritis italica (Miller) Greuter et Burdet essential oils. J. Ethnopharmacol. 2006, 107, 240-248.

21. Riela, S.; Bruno, M.; Formisano, C.; Rigano, D.; Rosselli, S.; Saladino, M.L.; Senatore, F. Effects of solvent-free microwave extraction on the chemical composition of essential oil of Calamintha nepeta (L.) Savi compared with the conventional production method. J. Sep. Sci. 2008, 31, 1110-1117.

22. Konakchiev, A.; Genova, E.; Couladis, M.. Chemical composition of the essential oil of Origanum vulgare ssp. hirtum (Link) Ietswaart in Bulgaria. C. R. Acad. Bulg. Sci. 2004, 57, 49-52.

23. Poulose, A.J.; Croteau, R. Biosynthesis of aromatic monoterpenes. Conversion of $\gamma$-terpinene to p-cymene and thymol in Thymus vulgaris L. Arch. Biochem. Biophys. 1978, 187, 307-314.

24. Werker, L.; Putievsky, E.; Ravid, U. The essential oils and glandular hairs in different chemotypes of Origanum vulgare L. Ann. Bot. 1985, 55, 793-801.

25. Putievsky, E.; Ravid, U.; Dudai, N. Phenological and seasonal influences on essential oil of a cultivated clone of Origanum vulgare L. J. Sci Food Agric. 1988, 43, 225-228. 
26. Jerković, I.; Mastelić, J.; Milos, M. The impact of both the season of collection and drying on the volatile constituents of Origanum vulgare L. ssp. hirtum grown wild in Croatia. Int. J. Food Sci. Technol. 2001, 36, 649-654.

27. Pérez, R.A.; Navarro, T.; de Lorenzo, C. HS-SPME analysis of the volatile compounds from spices as a source of flavour in 'Campo Real' table olive preparations. Flavour Frag. J. 2007, 22, 265-273.

28. D'Antuono, F.L.; Galletti, G.C.; Bocchini, P. Variability of essential oil content and composition of Origanum vulgare L. populations from a north mediterranean area (Liguria Region, Northern Italy). Ann. Bot. 2000, 86, 471-478.

29. Mockute, D.; Bernotiene, G.; Judzentiene, A. The essential oil of Origanum vulgare L. ssp. vulgare growing wild in Vilnius district (Lithuania). Phytochemistry 2001, 57, 65-69.

30. Panizzi, L.; Flamini, G.; Cioni, P.L.; Morelli, I. Composition and antimicrobial properties of essential oils of four Mediterranean Lamiaceae. J. Ethnopharmacol. 1993, 39, 167-170.

31. Sivropoulou, A.; Papanikolaou, E.; Nikolaou, C.; Kokkini, S.; Lanaras, T.; Arsenakis, M. Antimicrobial and cytotoxic activities of Origanum essential oils. J. Agric. Food Chem. 1996, 44, 1202-1205.

32. Aligiannis, N.; Kalpoutzakis, E.; Mitaku, S.; Chinou, I.B. Composition and antimicrobial activity of the essential oils two Origanum species. J. Agric. Food Chem. 2001, 49, 4168-4170.

33. Baydar, H.; Sagdic, O.; Ozkan, G.; Karadogan, T. Antibacterial activity and composition of essential oils from Origanum, Thymbra and Satureja species with commercial importance in Turkey. Food Control 2004, 15, 169-172.

34. Loźienè, K.; Venskutonis P.R.; Šipailienè A.; Labokas J. Radical scavenging and antibacterial properties of the extracts from different Thymus pulegioides L. chemotypes. Food Chem. 2007, 103, 546-559.

35. Ipek, E.; Zeytinoglu, H.; Okay, S.; Tuylu, B.A.; Kürkcüoglu, M.; Başer, K.H.C. Genotoxicity and antigenotoxicity of Origanum oil and carvacrol evaluated by Ames Salmonella/microsomal test. Food Chem. 2005, 93, 551-556.

36. Mazzanti, G.; Battinelli, L.; Salvatore, G. Antimicrobial properties of the linalol -rich essential oil of Hyssopus officinalis L. var decumbens (Lamiaceae). Flavour Frag. J. 1998, 13, 289-294.

37. Sokovic, M.; van Griensven, L.J.L.D. Antimicrobial activity of essential oils and their components against the three major pathogens of the cultivated button mushroom, Agaricus bisporus. Eur. J. Plant Pathol. 2006, 116, 211-224.

38. Alviano, W.S.; Mendonca-Filho, R.R.; Alviano, D.S.; Bizzo, H.R.; Souto-Padron, T.; Rodrigues, M.L.; Bolognese, A.M.; Alviano, C.S.; Souza, M.M.G. Antimicrobial activity of Croton cajucara Benth linalool-rich essential oil on artificial biofilms and planktonic microorganisms. Oral Microbiol. Immun. 2005, 20, 101-105.

39. Jirovetz, L.; Buchbauer, G.; Denkova, Z.; Stoyanova, A.; Murgov, I.; Schmidt, E.; Geissler, M. Antimicrobial testings and gas chromatographic analysis of pure oxygenated monoterpenes 1,8cineole, $\alpha$-terpineol, terpinen-4-ol and camphor as well as target compounds in essential oils of pine (Pinus pinaster), rosemary (Rosmarinus officinalis), tea tree (Melaleuca alternifolia). Sci. Pharm. 2005, 73, 27-39. 
40. Lai, K.P.; Ye, Y.Q.; Wie, Z.M.; Wang, G.Y.; Yang, H.Q. Study on antimicrobial activities of $\alpha$ (L)- terpineol against plant pathogens. Huagong Jishu Yu Kaifa 2007, 36, 5-7, via Chem.Abs.148:511007, 2008.

41. Queiroga, C.L.; Teixeira Duarte, M.C.; Baesa Ribeiro, B.; Melillo de Magalhaes, P. Linalool production from the leaves of Bursera aloexylon and its antimicrobial activity. Fitoterapia 2007, 78, 327-328.

42. Kamatou, G.P.P.; Viljoen, A.M. Linalool-a review of a biologically active compound of commercial importance. Nat. Prod. Commun. 2008, 3, 1183-1192.

43. Oyedemi, S.O.; Okoh, A.I.; Mabinya, L.V.; Pirochenva, G.; Afolayan, A.J. The proposed mechanism of bactericidal action of eugenol, $\alpha$-terpineol and $\gamma$-terpinene against Listeria monocytogenes, Streptococcus pyogenes, Proteus vulgaris and Escherichia coli. Afr. J. Biotechnol. 2009, 8, 1280-1286.

44. Formisano, C.; Rigano, D.; Senatore, F.; Al-Hillo, M.R.Y.; Piozzi, F.; Rosselli, S. Analysis of essential oil from Teucrium maghrebinum Greuter et Burdet growing wild in Algeria. Nat. Prod. Commun. 2009, 4, 411-414.

45. Jennings, W.; Shibamoto T. Qualitative Analysis of Flavour and Fragrance Volatiles by Glass Capillary Gas Chromatography; Academic Press: New York, NY, USA, 1980.

46. Davies, N.W. Gas chromatographic retention indices of monoterpenes and sesquiterpenes on methyl silicone and Carbowax 20M phases. J. Chromatogr. 1990, 503, 1-24.

47. Adams, R.P. Identification of Essential Oil Components by Gas Chromatography/Mass Spectrometry, 4th ed.; Allured Publishing: Carol Stream, IL, USA, 2007.

48. Barry, A. The Antimicrobic Susceptibility Test: Principles and Practices; Lea and Febiger: Philadelphia, PA, USA, 1976.

49. Bonsignore, L.; Loy, G.; Secci, D.; Delogu, A.; Palmieri, G. A preliminary microbiological screening of Sardinian pants. Fitoterapia 1990, 61, 339-341.

50. Koneman, E.W.; Allen, S.D.; Janda, W.M.; Schreckenberg, P.C.; Winn, W.C. Color Atlas and Textbook of Diagnostic Microbiology; Lippincott-Raven: Philadlphia, PA, USA, 1997; pp. 784-785.

51. Burt, S. Essential oils: their antibacterial properties and potential applications in foods-a review. Int. J. Food Microbiol. 2004, 94, 223-253.

52. Sahin, F.; Güllüce, M.; Daferera, D.; Sökmen, A.; Sökmen, M.; Polissiou, M.; Agar, G.; Özer, H. Biological activities of the essential oils and methanol extract of Origanum vulgare ssp. vulgare in the Eastern Anatolia region of Turkey. Food Control 2004, 15, 549-557.

53. Valero, M.; Giner, M.J. Effects of antimicrobial components of essential oils on growth of Bacillus cereus INRA L2104 in and the sensory qualities of carrot broth. Int. J. Food Microbiol. 2006, 106, 90-94.

Sample Availability: Samples of the essential oils are available from the authors.

(C) 2009 by the authors; licensee Molecular Diversity Preservation International, Basel, Switzerland. This article is an open-access article distributed under the terms and conditions of the Creative Commons Attribution license (http://creativecommons.org/licenses/by/3.0/). 